\title{
Effect of temperature on passion fruit emergence and seedling vigor ${ }^{1}$
}

\author{
Antônio Gustavo de Luna Souto ${ }^{2}$, Jussara Cristina Firmino da Costa 2 , \\ Nathalia Luiza Ferreira Campos², Jéssica Laísca Fernanda de Azevedo², \\ Carlos Eduardo Magalhães dos Santos ${ }^{2^{*}}$
}

\begin{abstract}
Seedlings for commercial growing of passion fruit are preferentially acquired through seeds. Success in germination and seedling emergence, in turn, is influenced by the genetic constitution of the progenies and the thermal conditions imposed on the growth environment. The aim of this study was to evaluate the emergence and vigor of seedlings of passion fruit cultivars exposed to different temperatures. The experiment was conducted in a germination chamber at the Unidade de Ensino, Pesquisa e Extensão / Pomar Campus of the Department of Plant Science of the Universidade Federal de Viçosa (UFV). The study was carried out in $5 \times 3$ factorial arrangement, with five temperature ranges $\left(5-15,10-20,15-25,20-30\right.$ and $\left.25-35{ }^{\circ} \mathrm{C}\right)$ and three varieties of passion fruit (BRS Sol do Cerrado, BRS Gigante Amarelo and FB-200 Yellow Master) in a completely randomized design with six replications of 25 seeds per plot. The variables analyzed were the percentage, the speed index, and the average time of emergence, shoot length, total length, and seedling dry matter. The cultivars BRS Sol do Cerrado and BRS Gigante Amarelo exhibited seedling emergence of over $95 \%$ in the temperature ranges of $20-30{ }^{\circ} \mathrm{C}$ and $25-35{ }^{\circ} \mathrm{C}$. Alternating temperatures from $20-30{ }^{\circ} \mathrm{C}$ stimulates seedling emergence, seedling growth, and greater accumulation of seedling dry matter.
\end{abstract}

Index terms: Passiflora edulis Sims, cultivars, seeds, thermal conditions.

\section{Emergência e vigor de plântulas de maracujazeiro azedo em função da temperatura}

\begin{abstract}
RESUMO - A propagação de plantas de maracujazeiro azedo, em plantios comerciais, é realizada preferencialmente por meio de sementes. O sucesso da germinação e emergência de plântulas, por sua vez, é influenciado pela constituição genéticas das progênies e pelas condições térmicas impostas no ambiente. $\mathrm{O}$ objetivo neste trabalho foi avaliar a emergência e o vigor de plântulas de cultivares de maracujazeiro azedo sob exposição de diferentes temperaturas. O experimento foi conduzido em câmara de germinação na Unidade de Ensino, Pesquisa e Extensão/Pomar Campus pertencente ao Departamento de Fitotecnia da UFV. O trabalho foi desenvolvido em esquema fatorial $5 \times 3$, com cinco faixas de temperatura $\left(5-15 ; 10-20 ; 15-25 ; 20-30\right.$ e $\left.25-35{ }^{\circ} \mathrm{C}\right)$ e três cultivares de maracujazeiro azedo (BRS Sol do Cerrado, BRS Gigante Amarelo e FB-200 Yellow Master) no delineamento inteiramente casualizado e seis repetições de 25 sementes por parcela. As variáveis analisadas foram as percentagem, índice de velocidade e tempo médio de emergência, o comprimento da parte aérea e total e massa seca de plântula. As cultivares BRS Sol do Cerrado e BRS Gigante Amarelo apresentaram emergência de plântulas acima de $95 \%$ nas faixas de temperaturas de $20-30{ }^{\circ} \mathrm{C}$ e $25-35{ }^{\circ} \mathrm{C}$. Temperaturas alternadas $20-30^{\circ} \mathrm{C}$ estimulam a emergência, o crescimento e maior acúmulo de massa seca das plântulas.
\end{abstract}

Termos de indexação: Passiflora edulis Sims, cultivares, sementes, condições térmicas.

\section{Introduction}

The passion fruit plant (Passiflora edulis Sims), also known as yellow passion fruit (maracujazeiro amarelo), belongs to the Passifloraceae family, which includes 12 genera and around 600 species distributed across the tropical zones of America and Africa (Bernacci et al., 2008). In the industrial agriculture network, this species represents around $95 \%$ of commercial production of passion fruit, due to its excellent vigor, fruit yield, and juice content (Costa et al., 2011; Melleti, 2011).

Plant propagation of passion fruit in commercial fields is preferentially through seeds, seminiferous (Silva et al., 2015), but lack of uniformity of germination and seedling emergence is reported by producers and nurseries, which creates difficulties in raising quality seedlings and establishing productive orchards. This lack of uniformity is related to the

${ }^{1}$ Submitted on 09/28/2016. Accepted for publication on 12/14/2016.

${ }^{2}$ Departamento de Fitotecnia, Universidade Federal de Viçosa, 36570-900 - Viçosa, MG, Brasil.

*Corresponding author < carlos.magalhaes@ufv.br>

Journal of Seed Science, v.39, n.1, p.050-057, 2017 
dormancy process present in various species of Passifloraceae, as reported by Osipi and Nakagawa (2005) in Passiflora alata Dryander, by Zucareli et al. (2009) in Passiflora cincinnata Mast., and Zucareli et al. (2015) in Passiflora incarnata L.

Germination and, consequently, seedling emergence is a process of resuming metabolic activity of the embryonic axis, culminating in radicle emergence. It is a critical phase, associated with factors related to the physical, biochemical, and physiological processes of the seed (Marini et al., 2012; Taiz and Zeiger, 2013), which are dependent on environmental conditions such as temperature (Bewley et al., 2014; Zucareli et al., 2015).

Studies related to the effect of air temperature on germination of the passion fruit plant are essential for understanding ecophysiological and biochemical processes and how the seeds are influenced by the thermal conditions provided by the environment (Ferreira and Borghetti, 2004). There are minimum and maximum temperatures that represent the lower and upper limit of germination, and optimum temperatures under which the germination process occurs more quickly in a shorter space of time (Marcos-Filho, 2005).

The temperature affects moisture uptake and regulates the biochemical and enzymatic reactions that regulate metabolism, reactions that are involved in the germination process (Bewley et al., 2014; Flores et al., 2014). Germination is variable, depending on the species and even within cultivars of the same species (Andrade and Jasper, 2013; Lone et al., 2014); each species requires an optimal range of temperature for this process to occur in the most efficient manner.

Considering that the germination response of fruit-bearing species is dependent not only on air temperature conditions, but also on the genetic constitution of the progenies used, and that this information still needs to be clarified for the passion fruit crop, the aim of this study was to evaluate the effect of exposure to different temperature ranges on the emergence and seedling vigor of passion fruit cultivars.

\section{Materials and Methods}

The experiment was conducted in a germination chamber with control of photoperiod and temperature conditions at the Department of Plant Science of the University Federal of Viçosa, Viçosa, Minas Gerais, Brazil, in the period of January to February 2016.

The study was conducted in a $5 \times 3$ factorial arrangement ( 5 temperature ranges and 3 commercial cultivars of passion fruit) in a completely randomized design with six replications per treatment and 25 seeds per experimental unit. The ranges of alternating temperatures used were $5-15^{\circ} \mathrm{C}, 10-20^{\circ} \mathrm{C}, 15$ $25^{\circ} \mathrm{C}, 20-30{ }^{\circ} \mathrm{C}$ and $25-35^{\circ} \mathrm{C}$, and the passion fruit cultivars used were BRS Sol do Cerrado, BRS Gigante Amarelo, and FB-200 Yellow Master. Seeds of the passion fruit cultivars used were acquired from the Viveiros Flora Brasil, Araguari, Minas Gerais, Brazil.

The photoperiod was $8 \mathrm{~h}$, with lights on during the day and $16 \mathrm{~h}$ of lights out at night. The lower temperature was established under the conditions of absence of photoperiod and the higher temperature established under the condition of photoperiod. The passion fruit seeds were selected and standardized in regard to size and weight and sown in inert substrate (washed sand) at $2 \mathrm{~cm}$ depth and a $4 \mathrm{~cm}$ spacing between rows. The substrate was irrigated every $24 \mathrm{~h}$, maintaining moisture sufficient for favoring germination and seedling emergence.

Before the experiment was set up, an imbibition test of the passion fruit seeds was carried out at the respective mean temperatures used in the experiment so as to verify the speed and amount of water uptake. To do so, at each mean temperature of the ranges tested (namely, 10, 15, 20, 25 and $30^{\circ} \mathrm{C}$ ), 4 samples of 10 seeds of each cultivar were immersed in a beaker containing $50 \mathrm{~mL}$ of distilled water, and the amount of water taken up in periods of evaluation of 12, 24, 48 and $72 \mathrm{~h}$ after imbibition was evaluated. The amount of water imbibed in each period was measured through the difference between the final weight in each period of evaluation and the initial weight of the samples before imbibition, considering water density equal to 1 , which was expressed in milliliters ( $\mathrm{mL})$.

The number of emerged seedlings was counted daily from the 7 th to the 28 th day after sowing (DAS) to verify stabilization of germination, according to the methodology contained in the Rules for Seed Testing for the passion fruit seeds (Brasil, 2009). Emerged seedlings were considered to be those that had cotyledons fully expanded above the surface of the substrate. Following the methodology of Ferreira and Borghetti (2004), the percentage of emergence at 7, 14, 21, 28 DAS, the mean emergence time (MET) (Eq. 1) and the emergence speed index (ESI) (Eq. 2) were evaluated.

$$
\mathrm{MET}=\left(\sum \text { niti } / \sum \text { ni }\right) \quad \text { Eq. } 1
$$

in which ni = number of seeds that germinated in time "i"; $\mathrm{t} i=$ time after setting up the test; $\mathrm{i}=1$ to 28 days.

$$
\mathrm{ESI}=\mathrm{E} 1 / \mathrm{N} 1+\mathrm{E} 2 / \mathrm{N} 2+\ldots+\mathrm{En} / \mathrm{Nn} \quad \text { Eq. } 2
$$

in which E1, E2, ..., En = number of normal seedlings counted in the first, second, and last count; N1, N2, Nn = number of days of sowing to the first, second, and last count.

At the end of the experiment, shoot length (SL) and total length (TL) were evaluated with a ruler in millimeters. Soon after biometric measurements, the seedlings were placed 
in paper bags and then in a forced air circulation oven at a temperature of $65{ }^{\circ} \mathrm{C}$ for a period of $48 \mathrm{~h}$ until reaching constant weight to obtain individual dry matter (IDM) of the seedling, measured on a semi-analytic balance.

The values of emergence percentage were transformed into $\arcsin (\mathrm{x} / 100)^{0.5}$; however, the data presented in the tables and figures refer to the original data, for better understanding. The data obtained were subjected to analysis of variance by the $\mathrm{F}$ test at $5 \%$ probability. The mean values in regard to the temperature ranges and the cultivars of passion fruit plants and the interaction between them were compared by the Tukey test at 5\% probability. The GENES statistical software (Cruz, 2013) was used for data analysis.

\section{Results and Discussion}

The evolution of imbibition of the seeds of the passion fruit cultivars as affected by temperature and period are shown in Figure 1. The biggest volume of water imbibed by the passion fruit seeds was observed at the mean temperature of $30{ }^{\circ} \mathrm{C}$, with peak water uptake in the period of $72 \mathrm{~h}$ after imbibition for the cultivar BRS Sol do Cerrado, $24 \mathrm{~h}$ for BRS Gigante Amarelo, and $48 \mathrm{~h}$ for FB-200 Yellow Master (Figures $1 \mathrm{~A}, \mathrm{~B}$, and $\mathrm{C}$ ). At the mean temperature of $10^{\circ} \mathrm{C}$, lower water uptake of the seed of the passion fruit cultivars was observed, with the cultivar BRS Sol do Cerrado standing out. The mean temperatures of 15,20 and $25{ }^{\circ} \mathrm{C}$ showed a similar response in relation to water uptake by the seeds.

Marcos-Filho (2005) affirms that it is important to characterize the seed imbibition process because higher temperatures contribute to greater activation of the energy of water, increasing introduction of water into the seeds in a shorter space of time, favoring reactivation of the germination processes, with an increase in respiratory activity and release of energy for germination.

In the 'Mariana' hybrid tomato plant, Ferreira et al. (2013) found that temperatures higher than $30{ }^{\circ} \mathrm{C}$ led to greater water uptake by seeds in comparison to the control treatment (20$30^{\circ} \mathrm{C}$ ), and uptake was faster in the first $25 \mathrm{~h}$, determining this period as the first phase of germination. After this period, stabilization of seed moisture content was observed, characterizing it as phase II of germination. This phase is
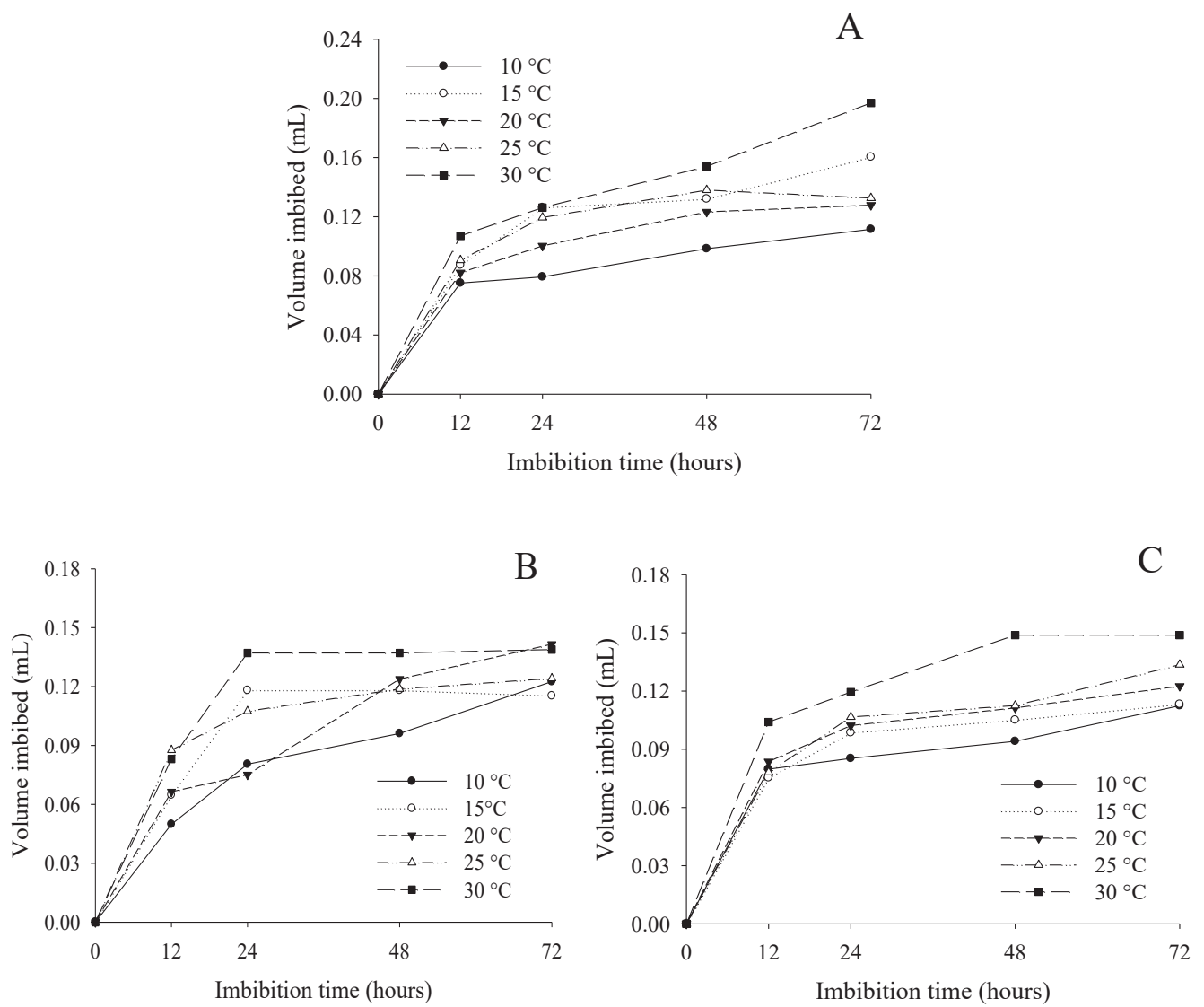

Figure 1. Volume of water imbibed by the seeds of passion fruit cultivars BRS Sol do Cerrado (A), BRS Gigante Amarelo (B), and FB-200 Yellow Master (C) according to imbibition time. 
recognized by drastic reduction in the speed of seed hydration (Marcos-Filho, 2005; Nonogaki et al., 2010).

When seeds were kept at temperatures of $5-15{ }^{\circ} \mathrm{C}$ and $10-20{ }^{\circ} \mathrm{C}$, there was no emergence of seedlings of the passion fruit cultivars in 28 DAS evaluated (Figures 2A, B, and C). At temperatures above these, emergence began at 13, 9 and 7 DAS in the temperature ranges of $15-25^{\circ} \mathrm{C}, 20-30{ }^{\circ} \mathrm{C}$ and $25-35^{\circ} \mathrm{C}$, and there was stability of emergence at 24,20 and 16 DAS, respectively.

The effect of temperature on germination of fruit-bearing plants has been widely studied in recent years, and it is possible to know the characteristics of each species in regard to ability for seedling propagation in determined locations and times of the year, which may also vary depending on the genetic, physiological, and physical quality and state of health of the seed (Andrade and Jasper, 2013); each species requires a determined range of temperature and an optimum temperature at which the germination process occurs with greater speed and uniformity (Alves et al., 2012).

From the results, it can be seen that the higher temperatures (20-30 ${ }^{\circ} \mathrm{C}$ and $25-35^{\circ} \mathrm{C}$ ) stimulate early development, a greater peak of emergence, and rapid stability of emergence. BRS Sol do Cerrado (Figure 2A) and BRS Gigante Amarelo (Figure 2B) were the cultivars that exhibited near totality of emerged seedlings. There is a differentiated response in regard to the requirement for a thermal range, and this is variable depending on the genetic material, as reported by Andrade and Jasper (2013) for varieties of papaya plant and Lone et al. (2014) for pitaya genotypes.

The emergence percentage evaluated in the periods of 7, 14, 21 and 28 DAS was affected by the temperature ranges and the cultivars used, with high mean values of emergence at the temperatures of $20-30{ }^{\circ} \mathrm{C}$ and $25-35{ }^{\circ} \mathrm{C}$ and inhibition of emergence at the temperatures of $5-15^{\circ} \mathrm{C}$ and $10-20^{\circ} \mathrm{C}$ (Table 1). In evaluation performed at 7 DAS, only the cultivars BRS Sol do Cerrado and FB-200 Yellow Master emerged when subjected to temperature alternating from $25-35{ }^{\circ} \mathrm{C}$; however, at $14 \mathrm{DAS}$, the cultivars BRS Sol do Cerrado and BRS Gigante Amarelo already exhibited more than $93 \%$ emergence at this temperature, indicating that high temperatures contribute to early germination and seedling emergence of passion fruit plants.

Exposure to low temperatures over a prolonged period can induce seed dormancy in species of the Passifloraceae family (Osipi and Nakagawa, 2005; Zucareli et al., 2009; Zucareli et al., 2015), reduced by the lower speed of water imbibition (Figure 1), without softening of the seed coat and, consequently, lack of protrusion of
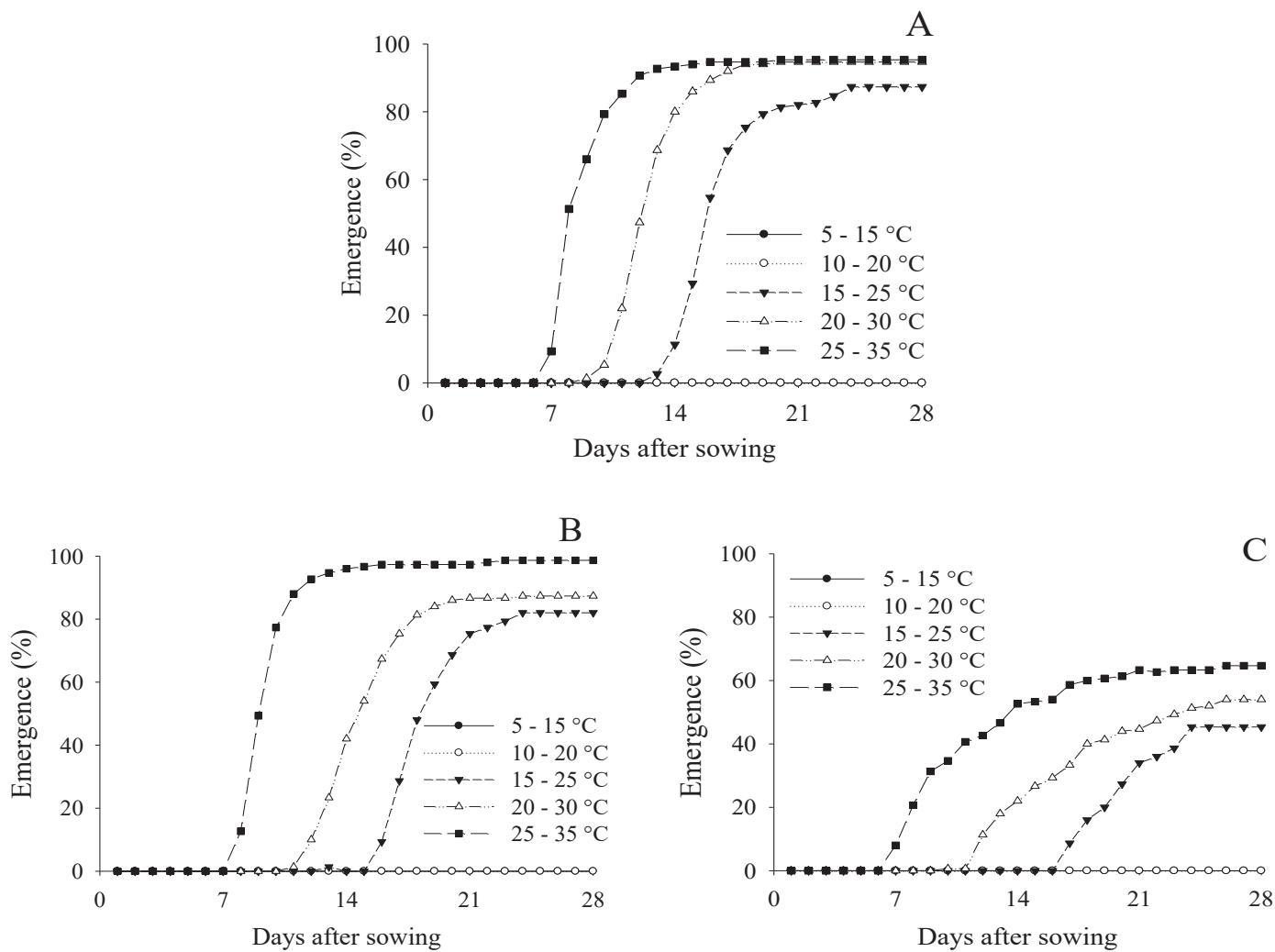

Figure 2. Evolution of emergence of the passion fruit seedlings, cultivars BRS Sol do Cerrado (A), BRS Gigante Amarelo (B), and FB-200 Yellow Master (C), evaluated up to the 28th day after sowing according to temperature ranges. 
Table 1. Seedling emergence of passion fruit cultivars at 7, 14, 21 and 28 days after sowing under different temperature ranges.

\begin{tabular}{|c|c|c|c|c|c|c|}
\hline & \multirow{2}{*}{ Cultivars } & \multicolumn{5}{|c|}{ Temperature range } \\
\hline & & $5-15^{\circ} \mathrm{C}$ & $10-20^{\circ} \mathrm{C}$ & $15-25^{\circ} \mathrm{C}$ & $20-30{ }^{\circ} \mathrm{C}$ & $25-35^{\circ} \mathrm{C}$ \\
\hline \multirow{4}{*}{ 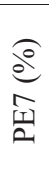 } & BRS Sol do Cerrado & $0 \mathrm{aB}$ & $0 \mathrm{aB}$ & $0 \mathrm{aB}$ & $0 \mathrm{aB}$ & $9.33 \mathrm{aA}$ \\
\hline & BRS Gigante Amarelo & $0 \mathrm{aA}$ & $0 \mathrm{aA}$ & $0 \mathrm{aA}$ & $0 \mathrm{aA}$ & $0 \mathrm{bA}$ \\
\hline & FB-200 Yellow Master & $0 \mathrm{aB}$ & $0 \mathrm{aB}$ & $0 \mathrm{aB}$ & $0 \mathrm{aB}$ & $8.00 \mathrm{aA}$ \\
\hline & \multicolumn{3}{|c|}{ Mean: 1.11} & \multicolumn{3}{|c|}{ CV (\%): 241.32} \\
\hline \multirow{4}{*}{ 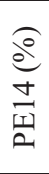 } & BRS Sol do Cerrado & $0 \mathrm{aB}$ & $0 \mathrm{aB}$ & $11.33 \mathrm{aB}$ & $80.00 \mathrm{aA}$ & $93.33 \mathrm{aA}$ \\
\hline & BRS Gigante Amarelo & $0 \mathrm{aC}$ & $0 \mathrm{aC}$ & $0 \mathrm{bC}$ & $42.00 \mathrm{bB}$ & $93.00 \mathrm{aA}$ \\
\hline & FB-200 Yellow Master & $0 \mathrm{aC}$ & $0 \mathrm{aC}$ & $0 \mathrm{bC}$ & $22.00 \mathrm{cB}$ & $52.66 \mathrm{bA}$ \\
\hline & \multicolumn{3}{|c|}{ Mean: 26.48} & \multicolumn{3}{|c|}{ CV (\%): 31.09} \\
\hline \multirow{4}{*}{$\frac{\underset{d}{d}}{\stackrel{0}{2}}$} & BRS Sol do Cerrado & $0 \mathrm{aC}$ & $0 \mathrm{aC}$ & $82.00 \mathrm{aB}$ & $94.66 \mathrm{aA}$ & $94.66 \mathrm{aA}$ \\
\hline & BRS Gigante Amarelo & $0 \mathrm{aD}$ & $0 \mathrm{aD}$ & $75.33 \mathrm{aC}$ & $86.66 \mathrm{aB}$ & $97.33 \mathrm{aA}$ \\
\hline & FB-200 Yellow Master & $0 \mathrm{aD}$ & $0 \mathrm{aD}$ & $34.00 \mathrm{bC}$ & $44.66 \mathrm{bB}$ & $63.33 \mathrm{bA}$ \\
\hline & \multicolumn{3}{|c|}{ Mean: 44.88} & \multicolumn{3}{|c|}{ CV (\%): 13.81} \\
\hline \multirow{3}{*}{ 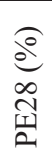 } & BRS Sol do Cerrado & $0 \mathrm{aB}$ & $0 \mathrm{aB}$ & $87.33 \mathrm{aA}$ & $94.66 \mathrm{aA}$ & $96.66 \mathrm{aA}$ \\
\hline & BRS Gigante Amarelo & $0 \mathrm{aC}$ & $0 \mathrm{aC}$ & $82.66 \mathrm{aB}$ & $88.00 \mathrm{aB}$ & $98.66 \mathrm{aA}$ \\
\hline & FB-200 Yellow Master & $0 \mathrm{aC}$ & $0 \mathrm{aC}$ & $49.33 \mathrm{bB}$ & $54.66 \mathrm{bAB}$ & $64.66 \mathrm{bA}$ \\
\hline
\end{tabular}

Mean values followed by the same lowercase letter in the line and uppercase letter in the column do not differ statistically by the Tukey's test; PE7 = \% of seedling emergence at 7 days; PE14 $=\%$ of seedling emergence at 14 days; PE21 = \% of seedling emergence at 21 days; PE28 $=\%$ of seedling emergence at 28 days.

the radicle (Marini et al., 2012). In addition, it reduces the activity of enzymes related to the germination process - lipase, amylase, and protease - and increases the activity of enzymes related to stress - superoxide dismutase and catalase (Marcos-Filho, 2005; Flores et al., 2014). While at a higher temperature up to a certain point, it contributes to accelerating the speed of water uptake and also to reactions that determine all the biochemical and enzymatic processes involved in germination (Marcos-Filho, 2005).

In evaluations performed at 14,21 and $28 \mathrm{DAS}$, it can be seen that the temperatures of $20-30{ }^{\circ} \mathrm{C}$ and $25-35^{\circ} \mathrm{C}$ stimulated the highest percentage of emerged seedlings, since more than $80 \%$ of the seeds of the cultivars BRS Sol do Cerrado and BRS Gigante Amarelo had already germinated at 14 DAS, with stability at 21 and 28 DAS, with emergence above 95\% (Table 2). For the cultivar FB-200 Yellow Master, in spite of the stimulus of temperature increase on emergence, the values remained below $65 \%$ of emerged seedlings, which may be linked to the genetic difference between the passion fruit plant materials or the quality of the seed lot acquired.

Evaluation of the physiological quality of the seeds is an important manner of verifying the vigor of seed lots for commercialization purposes, in which each species or cultivar within the same species can express its maximum genetic potential (Pilau et al., 2012; Andrade and Jasper, 2013). There are few studies showing the effect of temperature on germination of passion fruit plants (Passiflora edulis Sims). Pereira and Andrade (1994), evaluating the thermal effect on seeds of fruits that were acquired in a fruit market, found that the highest percentage of emergence was achieved at the alteration of temperature of $20-30{ }^{\circ} \mathrm{C}$.

The emergence speed index of the passion fruit seedlings increased with a rise in air temperature from $15-25{ }^{\circ} \mathrm{C}$ to 25 $35^{\circ} \mathrm{C}$, while at a temperature below the minimum one cited, there was no seedling emergence (Table 2). It can be seen that the cultivar BRS Sol do Cerrado at the temperature amplitude of $25-35^{\circ} \mathrm{C}$ had the highest absolute value of 3.069 in ESI, differing significantly from the other treatments. The lowest value of ESI was 0.643 for the cultivar FB-200 Yellow Master at the amplitude of $15-25^{\circ} \mathrm{C}$; however, there was an increase in the variable with a rise in thermal conditions, whereas in the cultivar BRS Gigante Amarelo, the ESI rose from 1.189 to 2.854 .

For MET, the shortest times were obtained at the temperature of $25-35{ }^{\circ} \mathrm{C}$, with mean values of 8.13 and 8.93 days for the cultivars BRS Sol do Cerrado and BRS Gigante Amarelo, respectively, and 10.5 days for the cultivar FB-200 Yellow Master (Table 2). Reduction in temperature increased the mean germination time, regardless of the cultivar, with values of 17.33 days at the temperature of $15-25{ }^{\circ} \mathrm{C}$; at temperature ranges below this, there was no seedling emergence.

The superiority in ESI and the shorter MET at higher temperatures may be related to an increase in imbibition of water supplied by irrigation (Figure 1) as a result of an increase in temperature of the medium, leading to increases in diffusion pressure and in metabolic and enzymatic reactions (Marini et al., 2012; Taiz and Zeiger, 2013) and reducing the internal 
water potential of the seed, allowing greater water uptake and better hydration (Bewley et al., 2014; Taiz and Zeiger, 2013). In other tropical fruit-bearing plants, higher emergence speed indexes have been obtained in high temperature conditions, as observed by Zucareli et al. (2015) in a wild species of passion fruits (Passiflora incarnata L.) and by Ferraz et al. (2012) in cupuaçu [Thebroma grandiflorum (Wild. ex. Spreng.)].

The total length (TL) and the shoot length (SL) of the passion fruit seedlings exhibited a significant difference among the cultivars and according to the thermal conditions to which they were subjected, in which temperatures less than or equal to the amplitude of $10-20{ }^{\circ} \mathrm{C}$ did not register values for these variables (Table 2).

Under the thermal conditions of $15-25^{\circ} \mathrm{C}$ and $20-30{ }^{\circ} \mathrm{C}$, the cultivar BRS Sol do Cerrado has higher values of TL and $\mathrm{SL}$ in relation to the other cultivars evaluated. However, at the temperature of $25-35{ }^{\circ} \mathrm{C}$, there was no statistical difference between the cultivars BRS Sol do Cerrado $(\mathrm{TL}-10.79 \mathrm{~cm}$ and $\mathrm{SL}-6.01 \mathrm{~cm})$ and BRS Gigante Amarelo $(\mathrm{TL}-10.61 \mathrm{~cm}$ and
SL $-5.75 \mathrm{~cm}$ ), whereas the cultivar FB-200 had the lowest values of TL and SL, regardless of the temperature established. This response may be related to the genetic difference among the cultivars tested, the physiological quality of the seeds, or the dormancy process, which is present in most of the species of the Passifloracea family (Welter et al., 2011).

Taiz and Zeiger (2013) and Oliveira and Lemes (2014) report that the increase in the thermal conditions of the air leads to an increase in metabolic activities, accelerating not only the germination process, but also embryo growth, with the mean temperature of $30^{\circ} \mathrm{C}$ being the optimum temperature for growth and development of most of the species (Ferreira and Borghetti, 2004).

The individual dry matter of the seedling was affected by the increase in air temperature, as can be seen in Table 3. The increase in the thermal amplitude from $15-25{ }^{\circ} \mathrm{C}$ to 20 $30{ }^{\circ} \mathrm{C}$ raised it from 8.931 to $11.588 \mathrm{mg}$, representing gains of $29.75 \%$. At low temperatures, Marcos-Filho (2005) reports that seed respiration occurred in a slower manner and the reserves

Table 2. Emergence speed index, mean emergence time, total length, and shoot length of seedlings of passion fruit cultivars under different temperature ranges.

\begin{tabular}{|c|c|c|c|c|c|c|}
\hline & \multirow{2}{*}{ Cultivars } & \multicolumn{5}{|c|}{ Temperature range } \\
\hline & & $5-15{ }^{\circ} \mathrm{C}$ & $10-20{ }^{\circ} \mathrm{C}$ & $15-25^{\circ} \mathrm{C}$ & $20-30{ }^{\circ} \mathrm{C}$ & $25-35^{\circ} \mathrm{C}$ \\
\hline \multirow{4}{*}{$\underset{\mathscr{\sim}}{*}$} & BRS Sol do Cerrado & $0 \mathrm{aD}$ & $0 \mathrm{aD}$ & $1.432 \mathrm{aC}$ & $2.051 \mathrm{aB}$ & $3.069 \mathrm{aA}$ \\
\hline & BRS Gigante Amarelo & $0 \mathrm{aD}$ & $0 \mathrm{aD}$ & $1.189 \mathrm{bC}$ & $1.601 \mathrm{bB}$ & $2.854 \mathrm{bA}$ \\
\hline & FB-200 Yellow Master & $0 \mathrm{aD}$ & $0 \mathrm{aD}$ & $0.643 \mathrm{cC}$ & $0.936 \mathrm{cB}$ & $1.777 \mathrm{cA}$ \\
\hline & Mean: 1.0 & & & & \multicolumn{2}{|c|}{ CV $(\%): 14.47$} \\
\hline \multirow{4}{*}{ 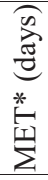 } & BRS Sol do Cerrado & $0 \mathrm{aD}$ & $0 \mathrm{aD}$ & $15.51 \mathrm{cA}$ & $11.79 \mathrm{cB}$ & $8.13 \mathrm{bC}$ \\
\hline & BRS Gigante Amarelo & $0 \mathrm{aD}$ & $0 \mathrm{aD}$ & $17.60 \mathrm{bA}$ & $13.9 \mathrm{bB}$ & $8.93 \mathrm{bC}$ \\
\hline & FB-200 Yellow Master & $0 \mathrm{aD}$ & $0 \mathrm{aD}$ & $18.88 \mathrm{aA}$ & $15.26 \mathrm{aB}$ & $10.50 \mathrm{aC}$ \\
\hline & Mean: 8.0 & & & & \multicolumn{2}{|c|}{$\mathrm{CV}(\%): 8.78$} \\
\hline \multirow{4}{*}{$\underset{\Theta}{\stackrel{\Xi}{E}}$} & BRS Sol do Cerrado & $0 \mathrm{aD}$ & $0 \mathrm{aD}$ & $8.93 \mathrm{aC}$ & $10.05 \mathrm{aB}$ & $10.79 \mathrm{aA}$ \\
\hline & BRS Gigante Amarelo & $0 \mathrm{aD}$ & $0 \mathrm{aD}$ & $8.37 \mathrm{bC}$ & $9.44 \mathrm{bB}$ & $10.61 \mathrm{aA}$ \\
\hline & FB-200 Yellow Master & $0 \mathrm{aC}$ & $0 \mathrm{aC}$ & $7.34 \mathrm{cB}$ & $7.97 \mathrm{cAB}$ & $8.28 \mathrm{bA}$ \\
\hline & Mean: 5. & & & & \multicolumn{2}{|c|}{ CV (\%): 7.21} \\
\hline \multirow{4}{*}{$\underset{\varpi}{\stackrel{\Xi}{0}}$} & BRS Sol do Cerrado & $0 \mathrm{aD}$ & $0 \mathrm{aD}$ & $3.43 \mathrm{aC}$ & $4.63 \mathrm{aB}$ & $6.01 \mathrm{aA}$ \\
\hline & BRS Gigante Amarelo & $0 \mathrm{aD}$ & $0 \mathrm{aD}$ & $2.98 \mathrm{bC}$ & $4.28 \mathrm{abB}$ & $5.75 \mathrm{aA}$ \\
\hline & FB-200 Yellow Master & $0 \mathrm{aC}$ & $0 \mathrm{aC}$ & $2.67 \mathrm{cbB}$ & $3.95 \mathrm{bA}$ & $4.08 \mathrm{bA}$ \\
\hline & Mean: 2.5 & & & & \multicolumn{2}{|c|}{ CV $(\%): 12.18$} \\
\hline
\end{tabular}

Mean values followed by the same lowercase letter in the line and uppercase letter in the column do not differ statistically by the Tukey test. ESI* $=$ Emergence speed index (the zero values were due to non-emergence of seedlings at the respective temperatures) and MET* $=$ Mean emergence time (the zero values were due to non-emergence of seedlings at the respective temperatures); TL $=$ Total length of seedling and SL $=$ Shoot length of seedling.

Table 3. Individual dry matter of passion fruit seedlings under different temperature ranges.

\begin{tabular}{cccccc}
\hline & \multicolumn{5}{c}{ Temperature range } \\
\cline { 2 - 6 } IDM (mg) & $5-15{ }^{\circ} \mathrm{C}$ & $10-20{ }^{\circ} \mathrm{C}$ & $15-25^{\circ} \mathrm{C}$ & $20-30{ }^{\circ} \mathrm{C}$ & $25-35^{\circ} \mathrm{C}$ \\
\cline { 2 - 6 } & $0 \mathrm{c}$ & $0 \mathrm{c}$ & $8.931 \mathrm{~b}$ & $11.588 \mathrm{a}$ & $9.061 \mathrm{ab}$ \\
\cline { 2 - 6 }
\end{tabular}

Mean values followed by the same lowercase letter in the line do not differ statistically by the Tukey test at $5 \%$ probability. IDM $=$ Individual dry matter. 
are not used in a rapid manner, which may have negatively affected the use of these reserves by the seedlings of the passion fruit cultivars, interfering in dry weight gain.

Upon subjected the seedlings to the highest temperature $\left(25-35^{\circ} \mathrm{C}\right)$, a reduction in seedling dry matter of $21.80 \%$ was observed, even though a statistical difference between the ranges $20-30{ }^{\circ} \mathrm{C}$ and $25-35^{\circ} \mathrm{C}$ was not observed. Temperatures considerably higher than the optimum temperature for seedling growth and development contribute to degenerative transformations that bring about rapid consumption of seed reserves, which may affect respiration efficiency, leading to lower utilization in synthesis processes, with direct reflection on biomass accumulation in the seedlings (Patané et al., 2006; Marini et al., 2012).

\section{Conclusions}

The seeds of passion fruit cultivars germinate more quickly and promote greater stability of seedling emergence in the temperature ranges of $20-30{ }^{\circ} \mathrm{C}$ and $25-35{ }^{\circ} \mathrm{C}$ due to a greater rate in the process of water uptake by the seeds;

The range of $20-30{ }^{\circ} \mathrm{C}$ stimulates the emergence, growth, and greater accumulation of dry matter of the seedlings;

Temperature alternating between $5-15{ }^{\circ} \mathrm{C}$ and $10-20{ }^{\circ} \mathrm{C}$ inhibit germination, emergence, and seedling growth of passion fruit seedlings of all the cultivars analyzed.

\section{Acknowledgments}

The authors thank the 'Conselho Nacional de Desenvolvimento Científico e Tecnológico' (CNPq) for granting a scholarship to the first author and the 'Fundação de Amparo à Pesquisa do Estado de Minas Gerais (FAPEMIG)' for financial support (APQ-01655-14).

\section{References}

ALVES, E. U.; SANTOS-MOURA, S.S.; MOURA, M. F.; GUEDES, R. S.; ESTRELA, F.A. Germinação e vigor de sementes de Crataeva tapia L. em diferentes substratos e temperaturas. Revista Brasileira de Fruticultura, v.34, n.4, p.1208-1215, 2012. http://dx.doi. org/10.1590/S0100-29452012000400030

ANDRADE, R.A.; JASPER, S.P. Temperatura na emergência de quatro variedades de mamoeiro. Comunicata Scientiae, v.4, n.4, p.401-406, 2013. https://comunicatascientiae.com.br/comunicata/ article/view/272/211

BERNACCI, L.C.; SOARES-SCOTT, M.D.; JUNQUEIRA, N.T.V.; PASSOS, I.R.S.; MELETTI, L. M. M. Passiflora edulis SIMS: the correct taxonomic way to cite the yellow passion fruit (and of others colors). Revista Brasileira de Fruticultura, v.30, n.2, p.566-576,
2008. http://dx.doi.org/10.1590/S0100-29452008000200053

BEWLEY, J.D.; BRADFORD, K.J.; HILHORST, H.W.M.; NONOGAKI, H. Seeds: physiology of development, germination and dormancy. New York: Springer, 2014. 407p.

BRASIL. Ministério da Agricultura, Pecuária e Abastecimento. Regras para análise de sementes. Ministério da Agricultura, Pecuária e Abastecimento. Secretaria de Defesa Agropecuária. Brasília, DF: MAPA/ACS, 2009. 395p. http://www.agricultura.gov.br/arq_editor/ file/2946_regras_analise_sementes.pdf

COSTA, E.; SANTOS, L.A.R.; CARVALHO, C.; LEAL, P.A.M.; GOMES, V.A. Volumes de substratos comerciais, solo e composto orgânico afetando a formação de mudas de maracujazeiro-amarelo em diferentes ambientes de cultivo. Revista Ceres, v.58, n.2, p.216222, 2011. http://dx.doi.org/10.1590/S0034-737X2011000200013

CRUZ, C.D. GENES - a software package for analysis in experimental statistics and quantitative genetics. Acta Scientiarum. Agronomy, v.35, n.3, p.271-276, 2013. http://dx.doi.org/10.4025/ actasciagron.v35i3.21251

FERRAZ， I.D.K.; ALBUQUERQUE， M.C.F.; CALVI， G.P.; FARIAS, D.L. Critérios morfológicos e temperatura para avaliação da germinação das sementes de cupuaçu. Revista Brasileira de Fruticultura, v.34, n.3, p.905-914, 2012. http://dx.doi.org/10.1590/ S0100-29452012000300033

FERREIRA, A.G., BORGHETTI, F. Germinação: do básico ao aplicado. Porto Alegre: Artmed, 2004. 323 p.

FERREIRA, R.L.; FORTI, V.A.; SILVA, V.N.; MELO, S.C. Temperatura inicial de germinação no desempenho de plântulas e mudas de tomate. Ciência Rural, v.43, n.7, p.1189-1195, 2013. http://dx.doi.org/10.1590/S0103-84782013000700008

FLORES, A.V.; BORGES, E.E.L.; GUIMARÃES, V.M.; GONÇALVES, J.F.C.; ATAÍDE, C. M.; BARROS, D. P. Atividade enzimática durante a germinação de sementes de Melanoxylon brauna Schott sob diferentes temperaturas. Cerne, v.20, n.2, p.401408, 2014. http://dx.doi.org/10.1590/01047760201420031399

LONE, A.B.; COLOMBO, R.C.; FAVETTA, V.; TAKAHASHI, L.S.A.; FARIA, R.T. Temperatura na germinação de sementes de genótipos de pitaya. Semina: Ciências Agrárias, v.35, n.4, p.2251-2258, 2014. http://dx.doi.org/10.5433/16790359.2014v35n4Suplp2251

MARCOS-FILHO, J. Fisiologia de sementes de plantas cultivadas. Piracicaba: FEALQ, 2005. 495p.

MARINI, P.; MORAES, C.L.; MARINI, N.; MORAES, D.M.; AMARANTE, L. Alterações fisiológicas e bioquímicas em sementes de arroz submetidas ao estresse térmico. Revista Ciência Agronômica, v. 43, n. 4, p. 722-730, 2012. http://dx.doi.org/10.1590/ S1806-66902012000400014

MELLETI, L.M.M. Avanço na cultura do maracujazeiro no Brasil. Revista Brasileira de Fruticultura, v.33, n.1, p. 83-91, 2011. http:// dx.doi.org/10.1590/S0100-29452011000500012 
NONOGAKI, H.; BASSEL, G.W.; BEWLEY, J.D. Germination still a mystery. Plant Science, v.179, n. 6, p. 574-581, 2010. http:// dx.doi.org/10.1016/j.plantsci.2010.02.010

OLIVEIRA, A.K.M.; LEMES, F.T.F. Germinação de sementes e formação de plântulas de Lafoensia pacari sob diferentes temperaturas. Comunicata Scientiae, v.5, n.4, p.471-477, 2014. https://comunicatascientiae.com.br/comunicata/article/view/148

OSIPI, E.A.F.; NAKAGAWA, J. Temperatura na avaliação da qualidade fisiológica de sementes do maracujá-doce (Passiflora alata Dryander). Revista Brasileira de Fruticultura, v.27, n.1, p. 179-191, 2005. http://dx.doi.org/10.1590/S0100-29452005000100048

PATANÉ, C.; CAVAllaro, V.; AVOlA, G.; D’AGOSTA, G. Seed respiration of sorghum [Sorghum bicolor (L.) Moench] during germination as affected by temperature and osmoconditioning. Seed Science Research, v.16, n.4, p.251-260, 2006. http://dx.doi. org/10.1017/SSR2006259

PEREIRA, T.S.; ANDRADE, A.C.S. Germinação de Psidium guajava L. e Passiflora edulis Sims - Efeito da temperatura, substrato e morfologia do desenvolvimento pós-seminal. Revista Brasileira de Sementes, v.16, n.1, p.58-62, 1994. http://www.abrates.org.br/ revista/artigos/1994/v16n1/artigo12.pdf

PILAU, F.G.; SOMAVILLA, L.; BATTISTI, R.; SCHWERZ, L.; KULCZYNSKI, S.M. Germinação de sementes de crambe em diferentes temperaturas e substratos. Semina: Ciências Agrárias, v.33, n.5, p.1825-1830, 2012. http://dx.doi.org/10.5433/16790359.2012v33n5p1825
SILVA, M.S.; OLIVEIRA, R.C.; ALMEIDA, R.F.; SÁ JUNIOR, A.; SANTOS, C.M. Aryl removal methods and passion fruit seed positions: Germination and emergence. Journal of Seed Science, v.37, n.2, p. 125-130, 2015. http://dx.doi.org/10.1590/2317$1545 \mathrm{v} 37 \mathrm{n} 2146373$

TAIZ, L.; ZEIGER, E. Fisiologia vegetal. Porto Alegre: Artmed, 2013. 954p.

WELTER, M.K.; SMIDERLE, O.J.; UCHÔA, S.C.P.; CHANG, M.T.; MENDES, E.P. Germinação de sementes de maracujá amarelo azedo em função de tratamentos térmicos. Revista Agro@mbiente On-line, v.5, n.3, p.227-232, 2011. http://dx.doi.org/10.18227/19828470ragro.v5i3.626

ZUCARELI, V.; FERREIRA, G.; AMARO, A.C.E.; ARAÚJO, F.P. Fotoperíodo, temperatura e reguladores vegetais na germinação de sementes de Passiflora cincinnata Mast. Revista Brasileira de Sementes, v. 31, n.3, p. 106-114, 2009. http://dx.doi.org/10.1590/ S0101-31222009000300012

ZUCARELI, V.; HENRIQUE, L.A.; ONO, E.O. Influence of light and temperature on the germination of Passiflora incarnata L. seeds. Journal of Seed Science, v.34, n.2, p.162-167, 2015. http://dx.doi. org/10.1590/2317-1545v37n2147082 